\title{
Effect of Egg Storage Temperature and Storage Period Pre-incubation on Hatchability of Eggs in Three Varieties of Japanese Quail
}

\author{
Khalid Hamid Hassan, Ali Rafea Abd Alsattar \\ Dept. of Animal Resources, College of Agriculture, University of Diyala, Baquba, Iraq
}

Email address:

Khaled@agriculture.uodiyala.edu.iq (K. H. Hassan)

To cite this article:

Khalid Hamid Hassan, Ali Rafea Abd Alsattar. Effect of Egg Storage Temperature and Storage Period Pre-incubation on Hatchability of Eggs in Three Varieties of Japanese Quail. Animal and Veterinary Sciences. Special Issue: Recent Trends in Animal Production and Healthcare. Vol. 3, No. 6-1, 2015, pp. 5-8. doi: 10.11648/j.avs.s.2015030601.12

\begin{abstract}
Background: There are many factors affecting successes of quail production system, one of important factor is provide sufficient number of egg for needs of hatcheries to produce chicks. This study was conducted in poultry farm of Animal Resources - College of Agriculture - University of Diyala - Iraq, to determine suitable conditions for storage of Japanese quail eggs belong to three varieties of Japanese quails( White, Black and brown plumage color ). Materials and Methods: Eggs from three varieties allocated in two groups represented two storage temperatures $7 \mathrm{C}^{\circ}$ and $20 \mathrm{C}^{\circ}$ (average room temperature ), and each temperature group divided into four sub-groups represented storage periods length $3,7,10$ and 14 days, thus the total number of egg groups were 16 groups. The experiment performed in factorial experiment $3 \times 2 \times 4$ for three factors included variety, storage temperature and storage period, conducted in Randomized Completely Blocks Design with three replicates. The experimental flock consist of 450 birds belong to three varieties, the eggs collected daily and stored according to these various treatments before entered the incubator, and after hatching of eggs, the data recorded for hatchability and embryonic mortality percentages for treatments. Results: The results showed that the black variety quail has significant superiority in fertility $(80.19 \%)$ with compare to White and Brown varieties (69.07 and $68.03 \%$ respectively). There were significant effect $(\mathrm{P}<0.05)$ of storage period on hatchability, hence there were significantly decline in hatchability after storage period for 14 days $(36.58 \%$ ), also there were significant interaction between varieties and storage periods. While there were no significant effect of storage temperature and other interactions on hatchability and embryonic mortality percentage.
\end{abstract}

Keywords: Japanese Quail, Varieties, Hatchability, Fertility, Embryonic Mortality

\section{Introduction}

Japanese quail represents smallest bird used in poultry industry for egg and meat production ${ }^{1}$, because of his unique traits such as fast growth and high rate of egg production ${ }^{2}$. There were increasing interest in quail production in Iraq during the few last year, and that reflect on many studies conducted in Iraq about viability and production performance of Japanese quail in the natural environment exhibited high adaptation for Iraqi conditions (Hassan ${ }^{3}$ and Hassan et al. ${ }^{4}$ ).

The important factor to activate the production system of quail is the production of quail chicks, involve in this process obtain a sufficient number of eggs to fill an Hatchery (Kuurmon et al. ${ }^{5}$ ).

Romao et al. ${ }^{6}$ reported that eggs from quails usually accumulated and storage over a period from 1 day up to 3 weeks before incubation. There are many factors affecting hatchability of stored eggs before incubation, for instance storage temperature and storage length period, Romao et al. ${ }^{6}$ also recorded that egg- type quail eggs had $85 \%$ hatchability when storage up to 10 days at $20 \mathrm{C}$ and $60 \%$ of relative humidity . In other study Garip and Dere ${ }^{7}$ reported that hatchability was $78.4 \%$ for quail eggs stored for 5 days in 21 $\mathrm{C}$ and hatchability declined to $35.4 \%$ when the storage period extended to 15 days in the same storage temperature.

The importance of storage temperature recorded by Meijerhof $^{8}$ who reported that low temperature prevent the embryonic development before incubation, and for this 
purpose the eggs room temperature must be $20-25 \mathrm{C}$ for $4-$ 7 days. Hassan ${ }^{1}$ reported that poultry breed classified into varieties according to plumage color or comb shape and may be depend on both. Alkan et al. ${ }^{9}$ explained that hatchability is affected by many factors as fertility of eggs, handling of eggs and conditions during incubation.

The aim of this study is to determine the effect of storage temperature and storage periods on hatchability of eggs quails belong to White, Black and Brown varieties of Japanese quail.

\section{Materials and Methods}

The experiment was carried out in poultry farm of Department of Animal Resources - College of Agriculture University of Diyala / Iraq. The experimental flock consist of 450 Japanese quail birds, belong to White , Black and Brown plumage represented three varieties. Hassan ${ }^{1}$ reported that the variety classification can be perform according to plumage color. Eggs from three varieties allocated in two groups represented two storage temperatures $7 \mathrm{C}^{\circ}$ and $20 \mathrm{C}^{\circ}$ (average room temperature ), and each temperature group divided into four sub-groups represented storage periods length $3,7,10$ and 14 days, thus the total number of egg groups were 16 groups. The experiment performed in factorial experiment $3 \times 2 \times 4$ for three factors included variety, storage temperature and storage period, conducted in Randomized Completely Blocks Design with three replicates. The eggs collected daily and stored according to these various treatments before entered the incubator ( the number of eggs were 344,337 and 280 eggs in the three batches respectively ), and after hatching of eggs , the data recorded for hatchability of total eggs, hatchability of fertile eggs and embryonic mortality percentages for treatments. The fertility of un hatching eggs determined by broken the egg and examined the embryonic development in each treatment groups

The birds fed ad libitum a diet containing $24 \%$ protein and $2896.8 \mathrm{kcal} / \mathrm{kg}$ metabolize energy.

The statistical analysis performed according factorial experiment $3 \times 2 \times 4$ in randomized complete block design with three replicates, and the significance of differences among means tested by Revised Least Significant Differences ( R.LSD) at $\mathrm{P}<0.05$. Analysis of variance performed by used SPSS program .

\section{Results}

The statistical analysis of variance showed that there were no significant effect of varieties and storage temperature on hatchability of total eggs, hatchability of fertile eggs and embryonic mortality percentages, while there were significant effect $(\mathrm{P}<0.05)$ of main effect of storage periods and also the interaction between variety and storage periods, the other interactions between factors showed no significant effect on the traits ( Table 1 ).
Table 1. Sources of variance and mean square for hatchability of eggs from three varieties in Japanese quail.

\begin{tabular}{lllll}
\hline S.O.V. & d. f. & $\begin{array}{l}\text { Hatchability } \\
\text { of total eggs }\end{array}$ & $\begin{array}{l}\text { Hatchability of Embryonic } \\
\text { fertile eggs }\end{array}$ & $\begin{array}{l}\text { Mortality } \\
\text { Hatches }\end{array}$ \\
\hline 2 & 301.77 & 145.35 & 145.35 \\
variety (A) & 2 & 370.76 & 226.3 & 226.3 \\
Temperature (B) & 1 & 1065.45 & 1771.51 & 1771.51 \\
Storage Period (C) & 3 & $1813.11^{*}$ & $1835.03^{*}$ & $1835.03^{*}$ \\
A $\times$ B & 2 & 398.52 & 503.08 & 503.08 \\
A $\times$ C & 6 & 965.01 & $1461.68^{*}$ & $1461.68^{*}$ \\
C $\times$ B & 3 & 1264.39 & 1651.71 & 1651.71 \\
A $\times$ B $\times$ C & 6 & 207.06 & 261.76 & 261.76 \\
Exper. Error & 46 & 499.69 & 622.86 & 622.86 \\
Total & 71 & & & \\
\hline
\end{tabular}

*Refer to significant effect at significant level $\mathrm{P}<0.05$

** Refer to highly significant effect at significant level $\mathrm{P}<0.01$.

The result reveled significant differences $(\mathrm{P}<0.05)$ among varieties in fertility (Fig. 1) hence the black variety recorded significant superiority in fertility as $80.19 \%$, while there were no significant differences between white and brown varieties in fertility as $69.07 \%$ and $68.03 \%$ respectively.

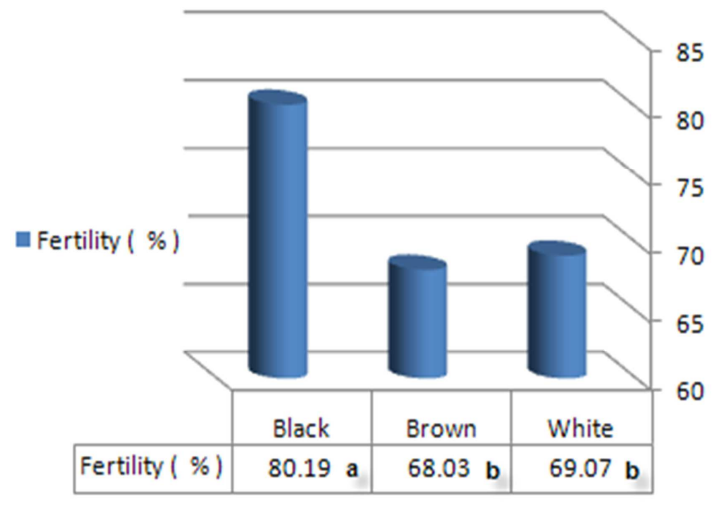

Fig. 1. Fertility of eggs in three varieties of Japanese quails.

Tavaniello ${ }^{10}$ confirm that heredity has affected role in fertility of quails, so there were differences between strains in fertility of their eggs.

While the results showed no significant differences among varieties in respect of hatchability of total eggs and hatchability of fertile eggs (Table 2).

Table 2. Means of Percentages of hatchability and embryonic mortality in three varieties of quails.

\begin{tabular}{llll}
\hline Variety & $\begin{array}{l}\text { Hatchability(\%) } \\
\text { of total eggs }\end{array}$ & $\begin{array}{l}\text { Hatchability(\%) } \\
\text { of fertile eggs }\end{array}$ & $\begin{array}{l}\text { Embryonic } \\
\text { Mortality(\%) }\end{array}$ \\
\hline White & 39.52 & 54.08 & 45.92 \\
Brown & 35.44 & 48.65 & 51.35 \\
Black & 43.3 & 48.89 & 51.11 \\
\hline
\end{tabular}

The storage temperature 7 and $20 \mathrm{C}^{\circ}$ showed also no significant differences in hatchability of total eggs (43.27 and $35.57 \%$ respectively) and hatchability of fertile eggs $(55.50$ and $45.58 \%$ ) as presented in Table 3 . 
Table 3. Means of Percentages of hatchability and embryonic mortality from two storage temperatures (C) in quails.

\begin{tabular}{llll}
\hline $\begin{array}{l}\text { Storage } \\
\text { temperature }\end{array}$ & $\begin{array}{l}\text { Hatchability(\%) } \\
\text { of total eggs }\end{array}$ & $\begin{array}{l}\text { Hatchability(\%) } \\
\text { of fertile eggs }\end{array}$ & $\begin{array}{l}\text { Embryonic } \\
\text { Mortality(\%) }\end{array}$ \\
\hline 19 & 43.27 & 55.5 & 44.5 \\
7 & 35.57 & 45.58 & 54.42 \\
\hline
\end{tabular}

Storage periods as mentioned previously showed significant effect on hatchability and embryonic mortality according to $\mathrm{F}$ test in the analysis of variance, and the post hoc test (Revised LSD) showed significant decline in hatchability of total eggs for 14 days storage period $(24.98 \%)$ compared with other periods which have no significant differences among them (Table 4).

Table 4. Mean Percentages of hatchability and embryonic mortality from various storage periods (day) in quails.

\begin{tabular}{llll}
\hline $\begin{array}{l}\text { Storage } \\
\text { periods (day) }\end{array}$ & $\begin{array}{l}\text { Hatchability(\%) } \\
\text { of total eggs }\end{array}$ & $\begin{array}{l}\text { Hatchability(\%) } \\
\text { of fertile eggs }\end{array}$ & $\begin{array}{l}\text { Embryonic } \\
\text { Mortality(\%) }\end{array}$ \\
\hline 3 & $47.67 \mathrm{a}$ & $58.43 \mathrm{a}$ & $41.57 \mathrm{a}$ \\
7 & $40.66 \mathrm{a}$ & $49.69 \mathrm{ab}$ & $50.31 \mathrm{ab}$ \\
10 & $44.38 \mathrm{a}$ & $57.46 \mathrm{a}$ & $42.54 \mathrm{a}$ \\
14 & $24.99 \mathrm{~b}$ & $36.58 \mathrm{~b}$ & $63.42 \mathrm{~b}$ \\
\hline
\end{tabular}

*Means with different letters significantly different at $\mathrm{P}<0.05$.

While the result recorded no significant differences between 7 days and 14 days periods in its affect on hatchability of fertile eggs (Table 4). This results agreed with Tavaniello ${ }^{10}$ who reported that successful hatches affected by the princubation period, and represent important factor.

The interaction between varieties and storage periods appear significant differences in hatchability of fertile eggs and embryonic mortality, The highest hatchability for black variety was at 3 days storage period $(73.76 \%)$, while the highest hatchability for brown variety was at 14 days $(52.09 \%)$, and the best hatchability for white variety appear at 10 days $(63.58 \%)$ as recorded in Table 5. These differences reflect the presence of variations in the suitable conditions needed for different genotypes as varieties and strains.

Table 5. Means of Percentages of hatchability and embryonic mortality of interaction between varieties of quails and storage periods (day) preincubation eggs.

\begin{tabular}{lllll}
\hline $\begin{array}{l}\text { Storage } \\
\text { periods }\end{array}$ & Variety & $\begin{array}{l}\text { Hatchability } \\
\text { total eggs }\end{array}$ & $\begin{array}{l}\text { Hatchability } \\
\text { fertile eggs }\end{array}$ & $\begin{array}{l}\text { Embryonic } \\
\text { Mortality }\end{array}$ \\
\hline \multirow{3}{*}{3} & White & 37.58 & 51.91 & 48.09 \\
& Brown & 41.65 & 49.63 & 50.37 \\
7 & Black & 63.75 & 73.76 & 26.24 \\
& White & 50.67 & 61.78 & 38.22 \\
& Brown & 38.18 & 49.84 & 50.16 \\
10 & Black & 33.14 & 37.44 & 62.56 \\
& White & 46.45 & 63.58 & 36.42 \\
& Brown & 28.94 & 43.02 & 56.98 \\
14 & Black & 57.74 & 65.79 & 34.21 \\
& White & 23.37 & 39.06 & 60.94 \\
& Brown & 33.01 & 52.09 & 47.91 \\
& Black & 18.59 & 18.59 & 81.41 \\
& & N.S. & $*$ & $*$ \\
\hline
\end{tabular}

*Refer to significant effect at significant level $\mathrm{P}<0.05$

N.S. $=$ Refer to no significant effect at significant level $\mathrm{P}<0.05$
In other hand, there were no significant differences recorded among hatchability result from interactions between storage temperature and varieties as showing in Table 6.

Table 6. Means of Percentages of hatchability and embryonic mortality of interaction between varieties of quails and storage temperatures (C) preincubation eggs.

\begin{tabular}{lllll}
\hline $\begin{array}{l}\text { Storage } \\
\text { temperature }\end{array}$ & Variety & $\begin{array}{l}\text { Hatchability } \\
\text { total eggs }\end{array}$ & $\begin{array}{l}\text { Hatchability } \\
\text { fertile eggs }\end{array}$ & $\begin{array}{l}\text { Embryonic } \\
\text { Mortality }\end{array}$ \\
\hline \multirow{3}{*}{20} & White & 38.93 & 53.84 & 46.16 \\
& Brown & 40.15 & 55.4 & 44.6 \\
& Black & 50.72 & 57.27 & 42.73 \\
& White & 40.11 & 54.33 & 45.67 \\
& Brown & 30.73 & 41.89 & 58.11 \\
& Black & 35.88 & 40.53 & 59.47 \\
\hline
\end{tabular}

N.S. $=$ Refer to no significant effect at significant level $\mathrm{P}<0.05$.

The study estimates the correlation coefficient between the factors included in the study (varieties, storage temperature and storage periods) and each of fertility, hatchability of total eggs, hatchability of fertile eggs and embryonic mortality as showing in Table 7.

Table 7. Spearman correlation coefficients between varieties, storage periods, storage temperatures and each traits included in the study.

\begin{tabular}{llll}
\hline & Fertility & $\begin{array}{l}\text { Hatchability total } \\
\text { eggs }\end{array}$ & $\begin{array}{l}\text { Hatchability } \\
\text { fertile eggs }\end{array}$ \\
\hline $\begin{array}{l}\text { Variety } \\
\begin{array}{l}\text { Storage } \\
\text { temperature }\end{array}\end{array}$ & $0.25^{*}$ & 0.06 & -0.08 \\
$\begin{array}{l}\text { Storage } \\
\text { periods }\end{array}$ & $-0.40^{* *}$ & -0.16 & -0.18 \\
\hline
\end{tabular}

* Mean correlation coefficient is significant at $\mathrm{P}<0.05$.

**Mean correlation coefficient is significant at $\mathrm{P}<0.01$.

The highly significant negative correlation between storage periods and fertility may be caused by undetected early embryonic mortality. While the storage periods have highly significant negative correlation coefficient with hatchability of total eggs (Table 7) may be reflect the un suitable conditions appear with the progress of storage as a result of loss of water from eggs and change in the $\mathrm{PH}$ of the egg.

\section{Discussion}

The results of this study showed a significant effect of varieties on fertility, the data showed superiority of black variety in this traits which may indicate for linkage or pleiotropic effect between the two traits, and significant correlation between variety and fertility may confirm this situation. The significant effect of storage periods on hatchability of total eggs and fertile eggs agreed with many previous studies (Garip and Dere ${ }^{7}$, Tavaniello ${ }^{10}$ ) have the same conclusion, that the prolonged storage period caused decline hatchability because of water loss and gas which lead to change $\mathrm{PH}$ of the interior environment of the egg, in this direction Garip and Dere ${ }^{7}$ reported that hatchability of quail 
eggs decline from $78.4 \%$ to $35.4 \%$ when stored in $21 \mathrm{C}^{\circ}$ for 5 and 15 days respectively. Also, there were highly significant negative correlation coefficient between storage periods and hatchability, and confirm the importance of the storage periods in the process of production quail chicks. Storage temperatures showed no significant differences between 7 and $20 \mathrm{C}^{\circ}$ included in the study which indicated that the two degrees in the suitable range of storage temperature.

\section{Conclusion}

According to the results of this study, in general the best storage period for Japanese quail was $7-10$ days in the room temperature $\left(20 \mathrm{C}^{\circ}\right)$. Also, there were important interaction between variety and storage periods, that indicate to presence of genotype- environment interactions.

\section{References}

[1] Hassan, K. H. 2011. Poultry Breeding. 1st Edition, Diyala University Press. Iraq.

[2] Sarabmeet Kaur, A. B. Mandal, K. B. Singh, M. M. Kadam.2008. The response of Japanese quails (heavy body weight line) to dietary energy levels and graded essential amino acid levels on growth performance and immunocompetnce. Livest. Sci., (2008), doi: 10.1016/j.livsci.12.019

[3] Hassan, K. H. 2013. Evaluation of productive performance of Japanese quail in summer of Iraq. Diyala Agricultural Science Journal, 5 (2): $69-80$.
[4] Hassan, K. H., A. A. Ahmad, T. A. Dawood, and N. K. Fadil. 2013. Study of dress percentage and relative weights of carcass parts in various ages of Japanese quail in Iraq. Diyala Agricultural Science Journal, 5 (2):92-103.

[5] Kuurman WW, Bailey BA, Koops WJ, Grossman M. 2002. Influence of storage days on the distribution for time of embryonic mortality during incubation. Poultry Science, 81:18.

[6] Romao J.M., Moraes T.G.V., Teixeira R.S.C., Cardoso W.M. and Buxade C.C. 2008. Effect of Egg Storage Length on Hatchability and Weight Loss in Incubation of Egg and Meat Type Japanese Quails. Brazilian Journal of Poultry Science, v. $10 /$ n.3 / $143-147$.

[7] Garip, M. and Dere S. 2011 . The effect of storage period and temperature on weight loss in quail eggs and the hatching weight of quail chicks. J. Anim. Vet. Adv. , 10 ( 18 ) : $2363-$ 2367.

[8] Meijerhof R. 1992. Pre-incubation holding of hatching eggs. Worlds Poultry Science Journal , 48:57-68.

[9] Alkan S., Karabag K., Galic A., Balcioglu M. S. 2008. Effects of genotype and egg weight on hatchability traits and hatching weight in Japanese quail. South African Journal of Animal Science 38, 231-237.

[10] Tavaniello S. Effect of cross-breed of meat and egg line on productive performance and meat quality in Japanese quail (Coturnix japonica) from different generations. PhD Thesis . UNIVERSITY OF MOLISE. 